Gut, 1987, 28, S1, 181-187

\title{
Adaptive responses to pharmacological inhibition of small intestinal $\alpha$-glucosidases in the rat
}

\author{
B LEMBCKE, C LÖSER, U R FÖLSCH, J WÖHLER, \\ AND W CREUTZFELDT
}

From the Division of Gastroenterology and Endocrinology, Department of Internal Medicine, University of Göttingen, Göttingen, FRG.

SUMMARY Intestinal adaptation (small intestinal weight and length, weight of the caecum and of the residual colon) to feeding different doses $(0-5-50-500 \mathrm{mg} / \mathrm{kg}$ bw) of the absorbable, competitive $\alpha$-glucosidase inhibitors BAY m 1099 and BAY o 1248 for three, seven, or 28 days was studied in rats. With the highest dose of either inhibitor, a significant and time dependent growth of the caecum was observed. Under these conditions, caecal tissue polyamine concentrations (spermidine and spermine) were slightly higher after three, unaffected after seven and slightly decreased after 28 days. Comparing the trophic effect both of BAY m 1099 and BAY o 1248 with that of the almost unabsorbed glucosidase inhibitor acarbose in fed rats showed that caecal weight was higher in response to the absorbed compounds than in response to acarbose, while total caecal carbohydrate content was unaffected by the absorbed and about nine fold increased by the unabsorbed inhibitors. These findings suggest that acarbose may partially inhibit bacterial carbohydrate degradation in the caecum.

The deoxynojirimycin derivatives BAY $m 1099$ (Miglitol; MW 207) and BAY o 1248 (MW 355) are potent competitive inhibitors of small intestinal $\alpha$ glucosidases, preferentially of glucoamylase (EC 3.2.1.3) and sucrase (EC 3.2.1.48) activity. ${ }^{12}$ These drugs, which are almost completely absorbed from the intestine, ${ }^{13}$ significantly suppress postprandial blood glucose increments and insulin responses after sucrose, ${ }^{4}$ starch $^{5}$ and a standardised breakfast. ${ }^{6}$ Therefore, therapeutic trials with BAY m 1099 and BAY o 1248 have been initiated in patients with diabetes mellitus. ${ }^{7}$

First data suggested that neither of these inhibitors would cause carbohydrate malabsorption in rats, ${ }^{1}$ but clinicopharmacological studies in healthy volunteers clearly showed dose related, significant carbohydrate malabsorption with either compound, both after sucrose or starch. ${ }^{58}$

In principle, administration of $\alpha$-glucosidase inhibitors at different doses enables study of intestinal adaptation in response to different degrees of carbohydrate malabsorption without manipulation of

Address for correspondence: Dr Bernhard Lembcke, Abteilung Gastroenterologie und Endokrinologie, Zentrum innere Medizin der Georg-AugustUniversität Göttingen, Robert-Koch-Str. 40, 3400 Göttingen, FRG. small intestinal integrity. Using the almost nonabsorbed $\alpha$-glucosidase inhibitor acarbose, trophic effects on small intestinal and caecal growth have been described earlier. ${ }^{9}$ In the distal gut, these effects were more pronounced, when the diet was fibre free.

Trophic sequelae of feeding absorbable $\alpha$-glucosidase inhibitors on the intestinal tract, however, have hitherto not been studied. Therefore, adaptive intestinal growth and corresponding tissue polyamine concentrations as potential mediators were studied during gradual pharmacological inhibition of $\alpha$ glucosidase activity with BAY m 1099 and BAY o 1248 in the rat.

\section{Methods}

ANIMALS

Female Wistar rats, body weight $175-210 \mathrm{~g}$, were used throughout ( $n=7-10 /$ group). Rats were fed a fibre rich $(6 \% \mathrm{w} / \mathrm{w})$ standard lab chow (Altromin ${ }^{\circledR}$, $58 \%$ carbohydrates, predominantly polysaccharides, $28 \%$ protein, $14 \%$ fat) and water ad libitum. Before death rats fasted overnight ( $>13$ hours). Once a day (between 6 and 8 pm), either BAY m 1099 (5-50- 


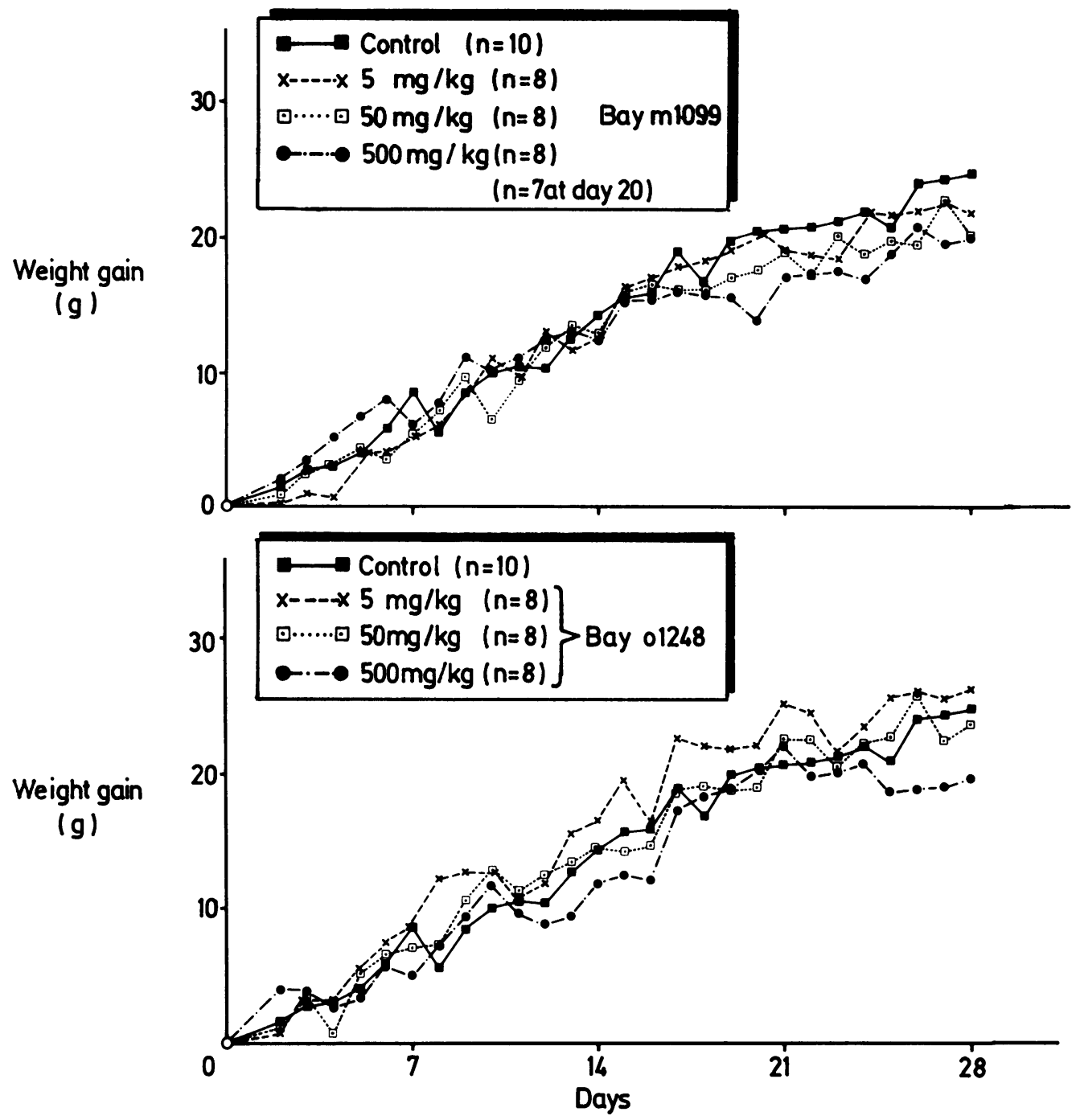

Fig. 1 Weight gain in control rats and those treated with either 5,50 , or $500 \mathrm{mg} / \mathrm{kg}$ bw, of BAY m 1099 (upper panel) or $B A Y$ o 1248 (lower panel) over 28 days (means of the indicated number of experimental animals).

$500 \mathrm{mg} / \mathrm{kg}$ bw), BAY o 1248 (5-50-500 mg/kg bw) or placebo (saline) were administered by oropharyngeal tube for three, seven, or 28 days. The $\mathrm{ED}_{50}$ of these inhibitors concerning the reduction of blood glucose responses following a sucrose or starch load in the rat is less than $0.5 \mathrm{mg} / \mathrm{kg} \mathrm{bw}{ }^{1}$

PARAMETERS

Weight (small intestine, caecum, colonic residue) and length (small intestine) were measured immediately after death, and drainage of the removed gut. Small intestinal mucosa was scraped off with a microscope glass slide, weighed, and homogenised under ice cold conditions to give a $2 \%$ homogenate. Protein was measured according to Lowry $e t$ al,${ }^{10}$ DNA according to Burton. ${ }^{11}$

Polyamine concentrations of caecal tissue were determined by HPLC and precolumn derivatisation with dansyl chloride. ${ }^{1213}$ 1,6-diaminohexane was used as internal standard. 1:10 (w/v) homogenates of the caecum were prepared with $30 \mathrm{mM}$ sodium phosphate buffer (pH 7.2) using an ultra-turrax homogeniser. Subsequent steps were deproteinisation by the addition of $3 \mathrm{ml} 0.2 \mathrm{M}$ perchloric acid to $1 \mathrm{ml}$ homogenate and dansylation by the addition of $0.3 \mathrm{ml}$ dansyl chloride ( $10 \mathrm{mg}$ in dry acetone) at $50^{\circ} \mathrm{C}$ for 12 
Table 1 Length and weight of the small intestine and weight of the colon during administration of different doses of $B A Y M$ 1099 or BAY o 1248 for various periods of time.

\begin{tabular}{|c|c|c|c|c|c|c|c|c|}
\hline \multirow[t]{2}{*}{ Segment } & \multicolumn{2}{|c|}{ Control } & \multicolumn{3}{|c|}{$B A Y m 1099$} & \multicolumn{3}{|c|}{$B A Y$ o 1248} \\
\hline & Day & (saline) & 5 & 50 & 500 & 5 & 50 & $500 \mathrm{mg} / \mathrm{kg} / \mathrm{bw}$ \\
\hline $\begin{array}{l}\text { Small intestine } \\
\text { length } \\
(\mathrm{m} / 100 \mathrm{~g} \mathrm{bw})\end{array}$ & $\begin{array}{r}3 \\
7 \\
28\end{array}$ & $\begin{array}{l}0.53 \pm 0.01 \\
0.52 \pm 0.01 \\
0.50 \pm 0.01\end{array}$ & $\begin{array}{l}0.54 \pm 0.02 \\
0.51 \pm 0.02 \\
0.48 \pm 0.01\end{array}$ & $\begin{array}{l}0.53 \pm 0.02 \\
0.53 \pm 0.01 \\
0.57 \pm 0.06\end{array}$ & $\begin{array}{l}0.55 \pm 0.02 \\
0.54 \pm 0.01 \\
0.55 \pm 0.01 \dagger\end{array}$ & $\begin{array}{l}0.53 \pm 0.01 \\
0.52 \pm 0.02 \\
0.49 \pm 0.01\end{array}$ & $\begin{array}{l}0.53 \pm 0.01 \\
0.55 \pm 0.02 \\
0.54 \pm 0.02\end{array}$ & $\begin{array}{l}0.53 \pm 0.03 \\
0.58 \pm 0.02 * \\
0.59 \pm 0.02 \ddagger\end{array}$ \\
\hline $\begin{array}{l}\text { weight } \\
(\mathrm{g} / 100 \mathrm{~g} \text { bw) }\end{array}$ & $\begin{array}{r}3 \\
7 \\
28\end{array}$ & $\begin{array}{l}2.78 \pm 0.10 \\
2.91 \pm 0.07 \\
2.95 \pm 0.08\end{array}$ & $\begin{array}{l}2.69 \pm 0.09 \\
2.72 \pm 0.11 \\
2.77 \pm 0.06\end{array}$ & $\begin{array}{l}2 \cdot 82 \pm 0.11 \\
2 \cdot 62 \pm 0.30 \\
3 \cdot 18 \pm 0.27\end{array}$ & $\begin{array}{l}3.04 \pm 0.08 \\
3.02 \pm 0.06 \\
3.02 \pm 0.07\end{array}$ & $\begin{array}{l}2 \cdot 80 \pm 0 \cdot 10 \\
3 \cdot 09 \pm 0 \cdot 10 \\
2 \cdot 81 \pm 0.06\end{array}$ & $\begin{array}{l}3 \cdot 01 \pm 0 \cdot 14 \\
3 \cdot 20 \pm 0 \cdot 12 \\
3 \cdot 10 \pm 0 \cdot 20\end{array}$ & $\begin{array}{l}2.85 \pm 0.09 \\
3.39 \pm 0.09 \ddagger \\
3.95 \pm 0.23 \ddagger\end{array}$ \\
\hline $\begin{array}{l}\text { Large intestine } \\
\text { weight of the } \\
\text { colon (except } \\
\text { the caecum) }\end{array}$ & 3 & $0.67 \pm 0.02$ & $0.61 \pm 0.02$ & $0.64 \pm 0.03$ & $0.67 \pm 0.02$ & $0.62 \pm 0.03$ & $0.69 \pm 0.05$ & $0.67 \pm 0.04$ \\
\hline$(\mathrm{g} / 100 \mathrm{~g} \mathrm{bw})$ & $\begin{array}{r}7 \\
28\end{array}$ & $\begin{array}{l}0.62 \pm 0.02 \\
0.72 \pm 0.01\end{array}$ & $\begin{array}{l}0.67 \pm 0.03 \\
0.66 \pm 0.01\end{array}$ & $\begin{array}{l}0.66 \pm 0.02 \\
0.73 \pm 0.08\end{array}$ & $\begin{array}{l}0.62 \pm 0.01 \\
0.75 \pm 0.03\end{array}$ & $\begin{array}{l}0.60 \pm 0.04 \\
0.66 \pm 0.02\end{array}$ & $\begin{array}{l}0.58 \pm 0.02 \\
0.70 \pm 0.03\end{array}$ & $\begin{array}{l}0.69 \pm 0.03 \\
0.85 \pm 0.05 \S\end{array}$ \\
\hline Rats (n) & & $\mathrm{n}=10$ & $\mathrm{n}=8$ & $\mathrm{n}=8$ & $\begin{array}{c}\mathrm{n}=8 \\
\text { (n=7 in the } \\
28 \text { days } \\
\text { group) }\end{array}$ & $\mathrm{n}=8$ & $\mathrm{n}=8$ & $\mathrm{n}=8$ \\
\hline
\end{tabular}

$* \mathrm{p} \leqslant 0.02 ; \uparrow \mathrm{p}<0.01 ; \ddagger \mathrm{p}<0.002 ; \S \mathrm{p}<0.05$

hours. Excess dansylchloride was removed by addition of $100 \mu \mathrm{l}$ proline $\left(100 \mathrm{mg} / \mathrm{ml} \mathrm{H}_{2} \mathrm{O}\right)$. The dansyl derivatives were extracted by toluene. Following evaporation of toluene, the dansylated polyamines were dissolved in $2 \mathrm{ml}$ methanol. For determination by reversed-phase HPLC, a C-18 Bischoff column and a Perkin-Elmer fluorescence photometer (activation at $345 \mathrm{~nm}$, emission at $500 \mathrm{~nm}$ ) were used. One analysis required five minutes with a $68-32 \mathrm{vol} \%$ and three minutes with a 93-7 vol. \% acetonitrile-water solution. The concentrations of putrescine, spermidine and spermine were expressed as $\mu \mathrm{g} / \mathrm{mg}$ DNA.

\section{INVESTIGATIONS IN FED RATS}

Additional experiments were carried out in fed rats to evaluate the role of luminal nutrient stimulation for caecal growth. The animals received either BAY m 1099, BAY o $1248(500 \mathrm{mg} / \mathrm{kg} \mathrm{bw})$, the $\alpha$-glucosidase inhibitor acarbose $(1000 \mathrm{mg} / \mathrm{kg} \mathrm{bw})$, which is hardly absorbed (about $0.6 \%)^{14}$ or saline along with standard chow for seven days. Immediately after death, the small intestine was divided into three segments of equal length, which, like the caecum, were separately rinsed with ice cold saline. Intestinal contents were analysed for their total carbohydrate content (measured as glucose units after total hydrolysis with sulphuric acid $\left({ }^{* *}\right)$ ). For comparison, these determinations were also carried out in (a) eight further, fasted rats, and (b) eight fasted rats treated with acarbose (1000 mg/kg bw).

** These determinations were kindly performed by Dr H Bischoff, Bayer AG, Wuppertal, FRG.
STATISTICAL ANALYSIS

Results are expressed as means \pm SEM. For statistical analysis, the Wilcoxon's U-test was used regarding a $\mathrm{p}<0.05$ significant.

\section{Results}

\section{WEIGHT GAIN}

With neither $\alpha$-glucosidase inhibitor and dosage (5, 50 , or $500 \mathrm{mg} / \mathrm{kg} \mathrm{bw}$ ) weight gain over 28 days (Fig. 1) was different from the controls. For correction of individual variation, however, weight of the respective intestinal segments was expressed per $100 \mathrm{~g}$ body weight.

\section{SMALL INTESTINE}

Moderate, but significant increments of total small intestinal length were observed with the highest dose $(500 \mathrm{mg} / \mathrm{kg})$ of BAY m 1099 after 28 days and BAY o 1248 after seven and 28 days (Table 1).

Concomitantly, a pronounced and apparently time dependent increase of small intestinal weight occurred with BAY o 1248 (500 mg/kg bw; p $<0.002$; Table 1). Total mucosal content of protein and DNA in the proximal and distal half of the small intestine dosedependently reveal a notable tendency towards higher values in the distal gut (Table 2).

3 LARGE INTESTINE

A significant, impressive and time dependent enlargement of the caecum (up to about $80 \%$ ) was shown with $500 \mathrm{mg} / \mathrm{kg}$ of either $\alpha$-glucosidase-inhibitor after 
Table 2 Mucosal protein and DNA content of the proximal and distal half of the small intestine (mg/segment $\times 100 \mathrm{~g}$ bw) during administration of different doses of BAY $m 1099$ or BAY o 1248 for 28 days

\begin{tabular}{|c|c|c|c|c|c|c|c|c|}
\hline \multirow[t]{2}{*}{ Parameter } & \multicolumn{2}{|l|}{ Control } & \multicolumn{3}{|c|}{$B A Y m 1099$} & \multicolumn{3}{|c|}{$B A Y \circ 1248$} \\
\hline & Segment & (saline) & 5 & $\begin{array}{l}50 \\
(\mathrm{mg} / \mathrm{kg} b w)\end{array}$ & 500 & 5 & $\begin{array}{l}50 \\
(m g / k g b w)\end{array}$ & 500 \\
\hline Protein & $\begin{array}{l}\text { Proximal half } \\
\text { Distal half }\end{array}$ & $\begin{array}{l}76 \cdot 8 \pm 4 \cdot 61 \\
79 \cdot 4 \pm 5 \cdot 8\end{array}$ & $\begin{array}{l}67 \cdot 5 \pm 6 \cdot 3 \\
70 \cdot 1 \pm 6 \cdot 4\end{array}$ & $\begin{array}{l}89 \cdot 5 \pm 9 \cdot 0 \\
98 \cdot 1 \pm 9 \cdot 3\end{array}$ & $\begin{array}{c}83 \cdot 6 \pm 5 \cdot 1 \\
103 \cdot 3 \pm 5 \cdot 7^{*}\end{array}$ & $\begin{array}{l}81 \cdot 7 \pm 7 \cdot 1 \\
97 \cdot 2 \pm 6 \cdot 4\end{array}$ & $\begin{array}{l}74 \cdot 3 \pm 11 \cdot 5 \\
83 \cdot 5 \pm 11 \cdot 3\end{array}$ & $\begin{array}{r}92 \cdot 9 \pm 10.9 \\
103 \cdot 6 \pm 9 \cdot 1 \dagger\end{array}$ \\
\hline DNA & $\begin{array}{l}\text { Proximal half } \\
\text { Distal half }\end{array}$ & $\begin{array}{l}3.81 \pm 0.27 \\
5.22 \pm 0.50\end{array}$ & $\begin{array}{l}3 \cdot 50 \pm 0.40 \\
5 \cdot 18 \pm 0.54\end{array}$ & $\begin{array}{l}3.96 \pm 0.60 \\
5.15 \pm 0.65\end{array}$ & $\begin{array}{l}3.22 \pm 0.64 \\
5.74 \pm 0.68\end{array}$ & $\begin{array}{l}3.42 \pm 0.65 \\
4.94 \pm 0.72\end{array}$ & $\begin{array}{l}4.01 \pm 0.50 \\
6.13 \pm 0.69\end{array}$ & $\begin{array}{l}5.07 \pm 0.67 \ddagger \\
6.61 \pm 0.50 \$\end{array}$ \\
\hline
\end{tabular}

$\dagger \mathrm{p} \leqslant 0.05 ;{ }^{*} \mathrm{p} \leqslant 0.02 ; \ddagger \mathrm{p}<0.01 ; \S 0.05<\mathrm{p}<0.10$
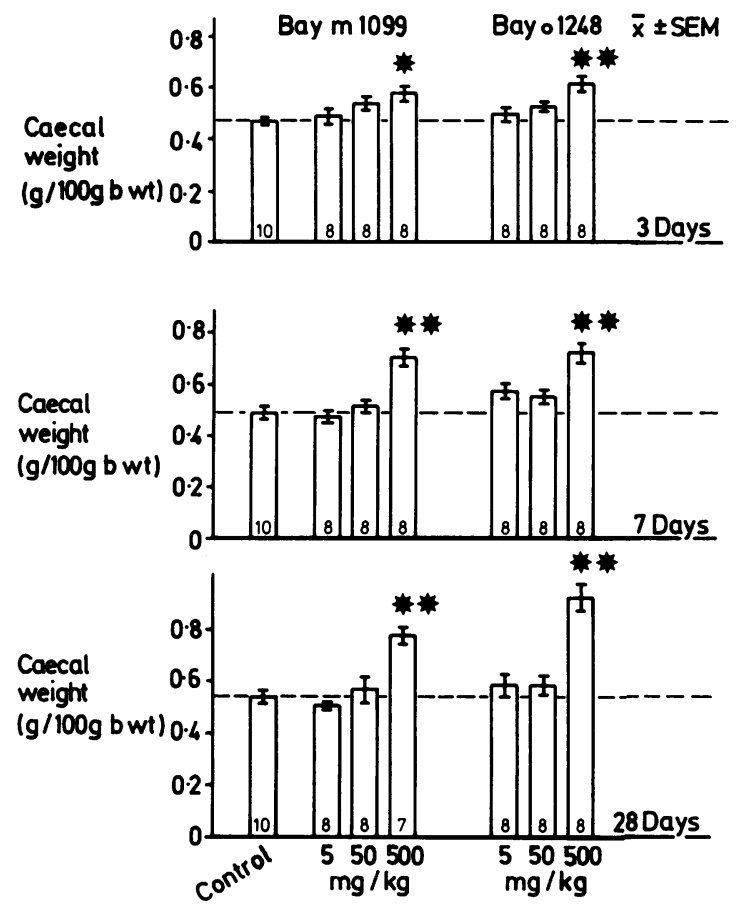

Fig. 2 Caecal weight $(\mathrm{g} / 100 \mathrm{~g} \mathrm{bw})$ in control rats and those treated with BAY 1099 or $B A Y$ o 1248 for 3, 7, or 28 days. Results are means $\pm S E M$ with the number of rats/ group indicated at the bottom of the respective bars. Asterisks indicate significant differences versus the respective control $\left({ }^{*} p<0.01 ;{ }^{* *} p<0.002\right)$.

three, seven, and 28 days (Fig. 2). Weight of the residual colon was not affected, however, unless the $500 \mathrm{mg} / \mathrm{kg}$ dose of BAY o 1248 was administered for 28 days (Table 1 ).

\section{POLYAMINES (SPERMIDINE, SPERMINE, PUTRESCINE)}

As caecal enlargement as a constant and significant
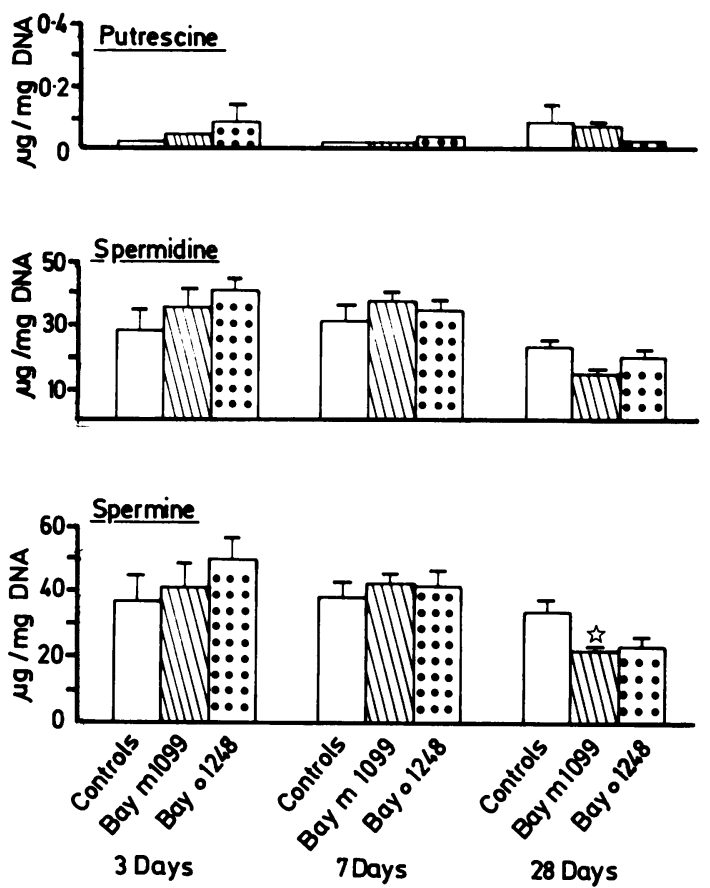

Fig. 3 Polyamine concentrations (putrescine, spermidine and spermine) in homogenates of the caecum of control rats and those treated with either BAY $m 1099$ or BAY o 1248, $500 \mathrm{mg} / \mathrm{kg} \mathrm{bw}$, for 3, 7 and 28 days. Means $\pm S E M$; asterisk indicates significant $(p<0.05)$ differences versus the respective control.

finding was confined to the highest dosage of either inhibitor, caecal tissue polyamine concentrations were investigated in rats treated with $500 \mathrm{mg} / \mathrm{kg}$ bw. BAY $\mathrm{m} 1099$ and BAY o 1248 for three, seven, or 28 days (and the respective controls) only.

After three days, and in correspondence with the trophic effect of pharmacologically induced carbohydrate malabsorption on the caecum (Fig. 2), polyamine concentrations (spermidine, spermine) 
Table 3 Protein and DNA concentration of the caecum (homogenate) during feeding of high doses of BAY m 1099 and $B A Y o 1248$

\begin{tabular}{|c|c|c|c|}
\hline $\begin{array}{l}\text { Period } \\
\text { (days) }\end{array}$ & Control & $\begin{array}{l}B A Y \mathrm{~m} 1099 \\
(500 \mathrm{mg} / \mathrm{kg} \mathrm{bw})\end{array}$ & $\begin{array}{l}B A Y \text { o } 1248 \\
(500 \mathrm{mg} / \mathrm{kg} \mathrm{bw})\end{array}$ \\
\hline $\begin{array}{l}3 \\
7 \\
28\end{array}$ & $\begin{array}{l}\text { Protein (mg } \\
405 \pm 48 \\
405 \pm 32 \\
303 \pm 26\end{array}$ & $\begin{array}{l}\text { caecum) } \\
336 \pm 16 \\
365 \pm 40 \\
460 \pm 44^{*}\end{array}$ & $\begin{array}{l}375 \pm 37 \\
321 \pm 26 \\
354 \pm 28\end{array}$ \\
\hline $\begin{array}{l}3 \\
7 \\
28\end{array}$ & $\begin{array}{l}\text { DNA }(\mathrm{mg} / \\
8.92 \pm 1.25 \\
7.35 \pm 1.00 \\
8.80 \pm 0.92\end{array}$ & $\begin{array}{l}\text { caecum) } \\
7 \cdot 27 \pm 0.83 \\
7 \cdot 16 \pm 0.93 \\
11 \cdot 10 \pm 1.08\end{array}$ & $\begin{array}{l}7.09 \pm 0.93 \\
6.72 \pm 0.81 \\
8.74 \pm 1.08\end{array}$ \\
\hline
\end{tabular}

tended to be higher in the treated rats than in the controls (Fig. 3 ).

After seven days, despite the even more pronounced trophic effect (Fig. 2), polyamine concentrations were identical in the controls and rats receiving either BAY m 1099 or BAY o 1248 (Fig. 3). After 28 days, polyamine concentrations were reduced (Fig. 3) despite further progress of caecal growth in the treated rats (Fig. 2).

Regarding individual polyamines, the pattern of spermidine and spermine concentrations was closely related, both with respect to their responses to either $\alpha$-glucosidase inhibitor and to time. With the reservation that caecal tissue concentrations were minimal, putrescine displayed a similar pattern.

As polyamine concentrations were calculated in relation to DNA-concentrations, the DNA concen- trations/g of caecum (together with caecal protein concentrations) are summarised in Table 3.

\section{NUTRIENT STIMULATION OF CAECAL GROWTH}

In the fed state and compared with controls, administration of BAY m 1099 and BAY o 1248 after seven days led to significantly higher amounts of carbohydrates in all segments of the small intestine, but not in the caecum (Table 4).

The predominantly unabsorbed $\alpha$-glucosidase inhibitor acarbose increased the luminal carbohydrate residue in the mid and distal small intestine and, at variance, induced a more than nine-fold rise of carbohydrates in the caecal content $(p<0.01)$.

Neither with BAY m 1099 nor with BAY o 1248 was the carbohydrate content of the caecum in fed rats higher than in the fasted state (Table 4). In fasted rats, acarbose did not induce significant increases in the carbohydrate content of the three small intestinal segments, but evoked accumulation of carbohydrateresidues in the caecum $(p<0.002)$ at a quantity resembling that in the fed state (Table 4). Regarding intestinal adaptation in the fed rat, however, BAY m 1099 and especially BAY o 1248 had more pronounced effects on small intestinal length and weight or caecal growth (Table 4) than did the "nonabsorbed' $\alpha$-glucosidase inhibitor acarbose.

\section{Discussion}

In conventional rats, the luminal presence of incompletely absorbed or digested substrates is a well known stimulus causing caecal enlargement. ${ }^{15}$

Table 4 Total glucose content of different intestinal segments during administration of the absorbable $\alpha$-glucosidase inhibitors $B A Y m 1099$ and BAY o 1248 (500 mg/kg bw) or the non-absorbed inhibitor acarbose (1000 mg/kg bw) for 7 days (fed and fasted rats).

\begin{tabular}{|c|c|c|c|c|c|c|c|c|}
\hline \multirow[t]{3}{*}{ Fed rats } & \multirow[b]{3}{*}{$n$} & \multicolumn{4}{|c|}{ umol glucose/segment } & \multicolumn{3}{|l|}{ Trophic effect } \\
\hline & & \multicolumn{3}{|l|}{ Small intestine } & \multirow[b]{2}{*}{ Caecum } & \multicolumn{2}{|l|}{ Small intestinal } & \multirow{2}{*}{$\begin{array}{l}\text { Caecal } \\
\text { weight } \\
(g / 100 \mathrm{gbw})\end{array}$} \\
\hline & & Prox & Mid & Dist & & $\begin{array}{l}\text { Length } \\
(\mathrm{m} / 100 \mathrm{gbw})\end{array}$ & $\begin{array}{l}\text { Weight } \\
(\mathrm{g} / 100 \mathrm{gbw})\end{array}$ & \\
\hline $\begin{array}{l}\text { Control } \\
\text { BAY m } 1099 \\
500 \mathrm{mg} / \mathrm{kg} \mathrm{bw}\end{array}$ & $\begin{array}{l}8 \\
8\end{array}$ & $\begin{array}{l}51 \cdot 3 \pm 9 \cdot 7 \\
86 \cdot 2 \pm 15 \cdot 6\end{array}$ & $\begin{array}{c}37 \cdot 7 \pm 6 \cdot 2 \\
141 \cdot 8 \pm 42 \cdot 3^{*}\end{array}$ & $\begin{array}{c}90 \cdot 1 \pm 14 \cdot 2 \\
307 \cdot 6 \pm 93 \cdot 6 \dagger\end{array}$ & $\begin{array}{l}201 \cdot 1 \pm 84 \cdot 2 \\
309 \cdot 6 \pm 69 \cdot 3\end{array}$ & $\begin{array}{l}0.45 \pm 0.01 \\
0.50 \pm 0.01^{*}\end{array}$ & $\begin{array}{l}2.64 \pm 0.10 \\
3.02 \pm 0.06^{*}\end{array}$ & $\begin{array}{l}0.49 \pm 0.03 \\
0.72 \pm 0.03 \ddagger\end{array}$ \\
\hline $\begin{array}{l}\text { BAY o } 1248 \\
500 \mathrm{mg} / \mathrm{kg} \text { bw }\end{array}$ & 8 & $128 \cdot 7 \pm 23 \cdot 2^{*}$ & $162 \cdot 7 \pm 40 \cdot 1 \ddagger$ & $379 \cdot 2 \pm 100 \cdot 5 \dagger$ & $244 \cdot 3 \pm 64 \cdot 7$ & $0.50 \pm 0.01 \S$ & $3 \cdot 30 \pm 0 \cdot 16 \ddagger$ & $0.76 \pm 0.02 \ddagger$ \\
\hline $\begin{array}{l}\text { Acarbose } \\
1000 \mathrm{mg} / \mathrm{kg} \text { bw }\end{array}$ & 8 & $92 \cdot 5 \pm 24 \cdot 4$ & $260 \cdot 3 \pm 76 \cdot 0^{*}$ & $523 \cdot 1 \pm 114 \cdot 3 \ddagger$ & $1882 \cdot 4 \pm 442 \cdot 4^{*}$ & $0.49 \pm 0.01 \S$ & $2 \cdot 92 \pm 0 \cdot 15$ & $0.61 \pm 0.04 \S$ \\
\hline \multicolumn{9}{|l|}{ Fasted rats } \\
\hline $\begin{array}{l}\text { Control } \\
\text { Acarbose } \\
1000 \mathrm{mg} / \mathrm{kg} \mathrm{bw}\end{array}$ & $\begin{array}{l}8 \\
8\end{array}$ & $\begin{array}{l}0.5 \pm 0.2 \\
3.4 \pm 1.8\end{array}$ & $\begin{array}{l}1 \cdot 6 \pm 0.7 \\
7 \cdot 0 \pm 4 \cdot 2\end{array}$ & $\begin{array}{l}10 \cdot 6 \pm 7 \cdot 6 \\
36 \cdot 9 \pm 20 \cdot 7\end{array}$ & $\begin{array}{c}267 \cdot 3 \pm 136 \cdot 7 \\
1623 \cdot 2 \pm 200 \cdot 0 \ddagger\end{array}$ & $\begin{array}{l}0.48 \pm 0.01 \\
0.52 \pm 0.01\end{array}$ & $\begin{array}{l}2.42 \pm 0.08 \\
3.09 \pm 0.12 \ddagger\end{array}$ & $\begin{array}{l}0.43 \pm 0.01 \\
0.55 \pm 0.02 \ddagger\end{array}$ \\
\hline
\end{tabular}

${ }^{*} \mathrm{p}<0.01 ; \dagger \mathrm{p}<0.02 ; \ddagger \mathrm{p}<0.002 ; \S \mathrm{p}<0.05$ 
Once having traversed the caecal valve, malabsorbed carbohydrates are subject to bacterial fermentation, ${ }^{17} 18$ thereby causing distension, which is likely to be the triggering factor for caecal enlargement. ${ }^{19}$ In compensated carbohydrate malabsorption - that is, without reduction of weight gain growth of the caecum and of the small bowel may reflect adaptive mechanisms for compensation, such as caecal fermentation and enlargement of the digestive-absorptive capacity (area).

In the rat, caecal growth is by far the more impressive trophic effect (Table 1; Fig. 1), thereby indicating that colonic (caecal) salvage ${ }^{17}$ is the major form of adaptation to carbohydrate malabsorption in our study.

Evaluating total small intestinal and caecal carbohydrate content in fed rats (Table 4) was a useful approach to further differentiate and substantiate this impression.

While the absorbed $\alpha$-glucosidase inhibitors did not cause accumulation of carbohydrate residues in the caecum, the almost unabsorbed $\alpha$-glucosidase inhibitor acarbose evoked an impressive increase of caecal carbohydrates. Interestingly, this amount of carbohydrates was only slightly higher in fed rats compared with those investigated after an overnight ( $>13$ hours) fast. These results are entirely compatible with the contention that acarbose - in contrast to the absorbed $\alpha$-glucosidase inhibitors - may partially diminish the bacterial degradation of malabsorbed carbohydrates in the caecum, which, finally, culminates in a less impressive effect on caecal enlargement (Table 4). If the inhibitor is absorbed during its passage through the small intestine, rapid bacterial fermentation in the caecum will lead to complete degradation of malabsorbed carbohydrates, resulting in the production of absorbable short chain fatty acids ${ }^{1820}$ and a low caecal carbohydrate content (Table 4). Caecal enlargement did not, however, show a stable relation to known mediators of trophic effects like the polyamines (Fig. 3).

In postresectional adaptation $(50 \%$ jejunal resection) it was shown ${ }^{21}$ that mucosal putrescine, spermidine and spermine concentrations return to normal within seven days after an early stage with increased polyamine concentrations. Our data are consistent with these results as far as polyamine synthesis after three and seven days is concerned. After 28 days, polyamines appeared to decrease significantly in

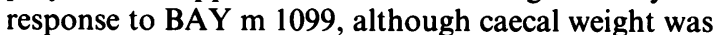
further increased. However, this finding might also be attributed to higher DNA-concentrations in this group of rats (Table 3 ).

No data are available on polyamine concentrations later than two weeks after the onset of intestinal growth.
In our study, despite progressive caecal enlargement from three to 28 days (Fig. 2), reflecting a permanent trophic stimulation of the caecum, only a poor and transient ( $<7$ days) rise of polyamine concentrations was detected. These findings might suggest that malabsorption of carbohydrates alone is a weak stimulus for initiation of polyamine synthesis, or that caecal growth in response to carbohydrate malabsorption is rather unrelated to tissue polyamine concentrations.

The mechanisms for this non-coherence of polyamines and trophic growth are unresolved. In principle, intracellular interference of absorbable 1deoxynojirimycin-derivatives with the polyamine pathway ${ }^{22}$ - for example, decreased activity of 'highmannose' glycosylated precursors of regulatory enzymes such as ornithine decarboxylase - in analogy to other enzymes ${ }^{23}$ - might be a potential mechanism, since 1-deoxynojirimycin and its $\mathrm{N}$-methyl-derivative are known to inhibit oligosaccharide processing in intestinal epithelial cells ${ }^{24}$ and $500 \mathrm{mg}$ of either inhibitor $/ \mathrm{kg}$ bw, is a pharmacotoxicological dose exceeding the proposed $\mathrm{ED}_{50} 1000$-fold. ${ }^{1}$ No direct evidence thus far, however, substantiates this speculation.

The inability to prove adaptive growth with 5 and $50 \mathrm{mg} / \mathrm{kg}$ bw of BAY m 1099 or BAY o 1248 , in part might be attributed to feeding standard chow instead of a fibre free or carbohydrate enriched diet. ${ }^{925}$ In view of the potency of these inhibitors ${ }^{2}$ however, and the high doses administered (10 and $\left.100 \times \mathrm{ED}_{50}\right)$, the lack of trophic effects was an unexpected finding. As a consequence, we cannot comment on the potential relevance of small and large intestinal adaptation in the clinicopharmacological situation.

In conclusion, feeding of even suprapharmacological dosages of the absorbable $\alpha$-glucosidase inhibitors BAY m 1099 and BAY o 1248 does not affect weight gain of rats over 28 days. It was shown that small intestinal growth hardly contributes to the underlying compensatory mechanisms, but caecal enlargement, reflecting fermentation, was of considerable significance. Limited evidence exists, that acarbose, at variance with the absorbable $\alpha$-glucosidase inhibitors, interferes with caecal fermentation, thereby allowing accumulation of substrate in the caecal sac (which, in the case of carbohydrate malabsorption, is rather likely to emphasise osmotic diarrhoea, but will mitigate the formation of intestinal gas). In the rat, these differences between absorbed and unabsorbed $\alpha$-glucosidase inhibitors resulted in different trophic effects on the caecum, thereby indicating that caecal fermentation plays a significant role as a trophic factor. 


\section{References}

1 Puls W, Krause HP, Müller L, Schutt H, Sitt R, Thomas G. Inhibitors of the rate of carbohydrate and lipid absorption by the intestine. Int J Obesity 1984 ; 8: suppl. 1: 181-90.

2 Lembcke B, Fölsch UR, Creutzfeldt W. Effect of 1-desoxynojirimycin derivatives on small intestinal disaccharidase activities and on intestinal transport in vitro. Digestion $1985 ; 31: 120-7$.

3 Rämsch K-D, Wetzelsberger N, Pütter J, Maul W. Pharmacokinetics and metabolism of the desoxynojirimycin derivatives BAY $\mathrm{m} 1099$ and BAY o 1248. Diabetes Res Clin Pract 1985 suppl. 1: 459/A.

4 Fölsch UR, Lembcke B, Lücke B, Hillebrand I, Ebert, R, Creutzfeldt W. Wirkung semisynthetischer Glucosidaseinhibitoren (BAY o 1248 und m 1099) auf Glucose, GIP und Insulin im Serum nach oraler Saccharosegabe. Akt Endokrin 1984; 5: 87/A.

5 Lembcke B, Fölsch UR, Gatzemeier W, Hillebrand I, Creutzfeldt W. Wirkung semisynthetischer $\alpha$-Glukosidaseinhibitoren (BAY m 1099 und BAY o 1248) auf Blutglukose, Insulin und GIP im Serum sowie die $\mathrm{H}_{2}$ Exhalation nach widerholter Stärkebelastung. Akt Endokrin 1985; 6: 97/A

6 Hillebrand I, Boehme K, Graefe KH, Wehling K. The effect of new $\alpha$-glucosidase inhibitors (BAY m 1099 and BAY o 1248) on meal-stimulated increases in glucose and insulin levels in man. Klin Wochenschr 1986; 64: 393-6.

7 Dimitriadis G, Raptis S, Raptis A, et al. Effects of two new $\alpha$-glucosidase inhibitors on glycemic control in patients with insulin-dependent diabetes mellitus. Klin Wochenschr 1986; 64: 405-10.

8 Lembcke B, Fölsch UR, Klausgrete E, Hillebrand I, Creutzfeldt W. Desoxynojirimycin-Derivate (BAY o 1248/BAY m 1099): welche Dosierung führt zur Kohlenhydrat-Malabsorption? Akt Endokrin 1984; 5: 104/A.

9 Creutzfeldt W, Fölsch UR, Elsenhans B, Ballmann M, Conlon JM. Adaptation of the small intestine to induced maldigestion in rats. Scand J Gastroenterol 1985; 20 Suppl. 112: 45-53.

10 Lowry OH, Rosebrough NJ, Farr AL, Randall RJ. Protein measurement with the Folin phenol reagent. $J$ Biol Chem 1951 ; 193: 265-9.

11 Burton KA. Study of the conditions and mechanism of the diphenylamine reaction for the colorimetric estimation of deoxyribonucleic acid. Biochem J 1956; 62: 31523.

12 Seiler N. Liquid chromatographic methods for assaying polyamines using prechromatographic derivatization. Methods Enzymol 1983; 94: 10-25.

13 Bontemps J, Laschet J, Dandrifosse G. Analysis of dansyl derivatives of di- and polyamines in mouse brain, human serum and duodenal biopsy specimens by highperformance liquid chromatography on a standard reversed-phase column. J Chromatogr 1984; 311: 5967.

14 Pütter J. Studies on the pharmacokinetics of acarbose in humans. In: U Brodbeck ed. Enzyme inhibitors. Weinheim: Verlag Chemie, 1980: 139-51.

15 Fischer JE. Effects of feeding diets containing lactose, agar, cellulose, raw potato starch or arabinose on the dry weight of cleaned gastrointestinal tract organs in the rat. Am J Physiol 1957; 188: 550-4.

16 Moinuddin JF, Lee W-T. Possible association of dietary residues with growth of the large gut. Am J Physiol 1959; 197: 903-11.

17 Bond JH, Levitt MD. Fate of soluble carbohydrate in the colon of rats and man. $J$ Clin Invest 1976; 57: 115864.

18 Flourie B, Florent C, Jouany J-P, Thivend P, Etanchaud $\mathrm{F}$, Rambaud J-C. Colonic metabolism of wheat starch in healthy humans. Gastroenterology 1985; 90, 111-9.

19 Gustafsson BE, Midtvedt T, Strandberg K. Effects of microbial contamination on the cecum enlargement of germfree rats. Scand J Gastroenterol 1970; 5: 309-14.

20 Ruppin, H, Bar-Meir S, Soergel KH, Wood CM, Schmitt MG. Absorption of short-chain fatty acids by the colon. Gastroenterology 1980; 78: 1500-7.

21 Luk GD, Baylin SB. Polyamines and intestinal growth - increased polyamine synthesis after jejunectomy. Am J Physiol 1983; 245: G656-60.

22 Luk GD, Baylin SB. Inhibition of intestinal epithelial DNA synthesis and adaptive hyperplasia after jejunectomy in the rat by suppression of polyamine synthesis. $J$ Clin Invest 1984; 74: 698-704.

23 Sjöström H, Noren O, Danielsen EM. Enzymatic activity of "high-mannose" glycosylated forms of intestinal microvillar hydrolases. J Pediatr Gastroenterol Nutr 1985; 4: 980-3.

24 Romero PA, Saunier B, Herscovics A. Comparison between 1-deoxynojirimycin and $\mathrm{N}$-methyl-1-deoxynojirimycin as inhibitors of oligosaccharide processing in intestinal epithelial cells. Biochem $J$ 1985; 226: 733-40.

25 Elsenhans B, Blume R, Caspary WF. Long-term feeding of unavailable carbohydrate gelling agents. Influence of dietary concentration and microbiological degradation on adaptive responses in the rat. Am J Clin Nutr 1981; 34: $1837-48$. 